\title{
Geochemical characteristics and genesis of coalbed methane in Baode area on the eastern margin of Ordos Basin
}

\author{
Weiqiang $\mathrm{Hu}^{1}{ }^{1}$, Xin Chen ${ }^{1}$, Yangbing $\mathrm{Li}^{1}$, Litao Ma ${ }^{1}$, Wang Yuesheng ${ }^{1}$, Cheng Liu ${ }^{1}$, Panpan $\mathrm{Li}^{1}$, Ying Huang ${ }^{1}$, Fang Qiao ${ }^{1}$, \\ Zaizhen Liu ${ }^{1}$, Chenchen $\mathrm{Li}^{1}$, Anlan $\mathrm{Li}^{1}$, and Duo Wang ${ }^{1}$
}

( ${ }^{1}$ CNOOC EnerTech-Drilling \& Production Co., Tianjin 300452, China)

\begin{abstract}
The degree of coalbed methane exploration and development now in Baode area is relatively low. The lack of systematic understanding of the formation of coalbed methane in this area restricts the further exploration and development of coalbed methane. Based on the comprehensive study on the geochemical characteristics of coalbed methane components, hydrocarbon isotopes, water quality detection and hydrogen oxygen isotopes in coal seam in Baode area, the origin of coalbed methane in this area is discussed. According to the research, the hydrocarbon gas in the composition of coalbed methane in Baode area is mainly $\mathrm{CH}_{4}$ and a small amount of ethane. Both of their drying coefficients are more than 0.99 , so they belong to the extremely dry coal bed methane. The value of $\delta^{13} \mathrm{C}\left(\mathrm{CH}_{4}\right)$ coalbed methane is on the low side and the value of $\delta^{13} \mathrm{C}\left(\mathrm{CO}_{2}\right)$ is on the high side, the mean value of $\delta \mathrm{D}\left(\mathrm{CH}_{4}\right)$ is $-247.5 \%$, which shows the characteristics of terrestrial biogas. The water produced by coal seam is weak alkaline and belongs to the $\mathrm{NaHCO}_{3}$ type of water. which is similar to the surface water ion composition, salinity , $\delta \mathrm{D}\left(\mathrm{H}_{2} \mathrm{O}\right)$ and $\delta^{18} \mathrm{O}\left(\mathrm{H}_{2} \mathrm{O}\right)$ values, indicating that the hydrodynamic conditions of the coal seam in this area are more active. There is a recharge of external water, which is benificial to the mass reproduction of $\mathrm{CH}_{4}$ producing bacteria and the formation of biogas. In this area, the coalbed methane is a mixture of thermogenic and biological genesis, mainly composed of thermogenic gases and supplemented by biogenic gases generated through carbon dioxide reduction.
\end{abstract}

\section{Introduction}

The Ordos Basin is China 's second largest oil-bearing basin on land. The western wing is steep and narrow, and the east wing is wide. It is an asymmetric large-scale superimposed craton basin ${ }^{[1-2]}$, which contains very rich coalbed methane resources ${ }^{[3-5]}$. During the exploration and development of coalbed methane in the Ordos Basin, it was found that the favorable area of coalbed methane is mainly located in the eastern edge of the basin. Rich coal seams have been found in Hancheng, Daning, Jixian, Liulin, Wubao and other places on the eastern edge of the basin Gas resources ${ }^{[6-8]}$, indicating that the eastern margin of the basin has huge potential for coalbed methane exploration and development.

The Baode area is located on the eastern edge of the Ordos Basin and is rich in coalbed methane resources ${ }^{[9-10]}$. Fracturing tests of CBM wells show that some wells have obtained industrial or low-production gas streams, indicating that the area has good prospects for CBM exploration. Due to the relatively low degree of CBM exploration and development in Baode area, the lack of systematic understanding of the cause of CBM in this area restricts further exploration and development in this area. Based on the experimental analysis of gas composition analysis, isotope analysis, and produced water quality analysis of coalbed methane wells in the study area, the author explores and analyzes the geochemical characteristics of coalbed methane and coalbed water produced in the study area, and the types of coalbed methane genesis. The formation approach and genetic mechanism provide guidance for subsequent exploration and development.

\section{Geological background}

The Baode area is located on the Jinxi flexure belt on the eastern edge of the Ordos Basin. It is a simple monoclinic structure with only local differences, and it is generally high in the east and low in the west [11-12]. Affected by tectonic sedimentary evolution, sea-level rise and fall, provenance supply and other factors, the Carboniferous-Permian strata have various sedimentary facies and lithological combinations [13-15]. Among them, the Taiyuan Formation mainly develops a set of sea-land interfacial coal-bearing sediments, consisting of coal seams, black carbonaceous mudstones, gray mudstones, grayish white sandstones, fine sandstones,

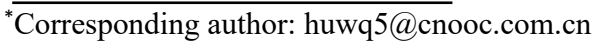


siltstones, argillaceous limestones, and bioclastic limestones. Shanxi Formation mainly develops a set of river delta coal-bearing sediments, consisting of coal seams, black carbonaceous mudstone, gray mudstone, gray siltstone mudstone, gray-white siltstone, medium-fine sandstone, and conglomerate. The coal seam development in Baode area is relatively stable. There are more than ten sets of uneven and thick coal seams, which are shallow overall. Among them, the No. $8+9$ coal seam of the Taiyuan Formation and the No. 4 +5 coal seam of the Shanxi Formation are relatively thick and belong to the main coal seams for exploration and development, which have commercial mining value.

\section{Sample collection and test analysis methods}

The gas component analysis, carbon isotope analysis and hydrogen isotope analysis were carried out by 34 samples of coalbed methane wells in Baode area of the eastern margin of Ordos Basin, and the water quality was detected by 13 samples of coalbed methane well effluent.

Gas composition analysis, stable isotope analysis, and water quality testing were all performed by the CNOOC EnerTech-Drilling \& Production Co. Feichanggui Central Labortory. Among them, the gas composition analysis was performed using an Agilent $7890 \mathrm{~B}$ gas chromatograph in accordance with the national standard GB/T 13610-2014 "Analysis of natural gas composipion-Gas chromatography". The stable isotope analysis was performed using the Elementar isoprime vision isotope mass spectrometer in accordance with international PDB standards and international SMOW standards, Repeat the test for the sample many times, so that the absolute deviation of the two isotopic measurement values is less than or equal to $\pm 1 \%$. The test results are shown in Tables 1 and Tables 2 . The water quality test uses the ICS-1100 ion chromatograph and DL77 potentiometer according to the industry Standard SY/T 5523-2016 "Method for " performs water quality testing. The test results are shown in Table 2.

\section{Results and discussion}

\subsection{Geochemical characteristics of coalbed methane}

\subsubsection{Coal bed gas composition and isotope characteristics}

The hydrocarbon components of coalbed methane (Table 1 ) in Baode area are mainly $\mathrm{CH} 4$, the volume fraction is $85.75 \% \sim 97.59 \%$, the mean value is $90.73 \%$; contains a small amount of ethane. The volume fraction is only $0.01 \% \sim 0.46 \%$, the average $0.12 \%$; the $\mathrm{C} 1 / \mathrm{C} 2$ values are all greater than 100, and the drying coefficient is greater than 0.99, which belongs to extremely dry CBM. Non-hydrocarbon components mainly contain $\mathrm{CO} 2$ and $\mathrm{N} 2$. Where the $\mathrm{CO} 2$ volume fraction is between $1.74 \% \sim 12.04 \%$ with a mean value of $6.20 \%$, and the N2 volume fraction is between $0.04 \%$ and $8.18 \%$ with a mean value of $2.92 \%$. The range of coalbed methane hydrocarbon isotope values in this region is wide (table $1)$. The $813 \mathrm{C}(\mathrm{CH} 4)$ value is between $-56.8 \%$ o $-47.7 \%$, the mean value is $-51.2 \%$, only very few wells $\delta 13 \mathrm{C}(\mathrm{CH} 4)$ less than $-55.0 \%$; the $\delta 13 \mathrm{C}(\mathrm{CO} 2)$ value is between $-6.6 \%$ 13.9\%o, the average value is $3.6 \%$; $\delta \mathrm{D}(\mathrm{CH} 4)$ value is between $-252.6 \% \sim-241.6 \%$, and the average value is $-247.5 \%$, all of which are less than $-170 \%$, which shows the characteristics of terrestrial biogas and thermogenic gas.

Table 1. Composition and isotope of coalbed methane in Baode area

\begin{tabular}{|c|c|c|c|c|c|c|c|c|c|}
\hline \multirow{2}{*}{ Project } & \multicolumn{4}{|c|}{ Volume fraction $/ \%$} & \multirow{2}{*}{$\mathrm{C}_{1} / \mathrm{C}_{2+}$} & \multirow{2}{*}{$\begin{array}{l}\text { Drying } \\
\text { coefficient }\end{array}$} & \multicolumn{3}{|c|}{ Isotope $/ \%$} \\
\hline & $\mathrm{CH}_{4}$ & $\mathrm{C}_{2} \mathrm{H}_{6}$ & $\mathrm{CO}_{2}$ & $\mathrm{~N}_{2}$ & & & $\delta^{13} \mathrm{C}\left(\mathrm{CH}_{4}\right)$ & $\delta^{13} \mathrm{C}\left(\mathrm{CO}_{2}\right)$ & $\delta \mathrm{D}\left(\mathrm{CH}_{4}\right)$ \\
\hline$\frac{\text { Max } \sim \text { Minimum }}{\text { average }}$ & $\frac{85.75 \sim 97.59}{90.73}$ & $\frac{0 .}{\frac{0 .}{0.46}} \frac{0.12}{0.12}$ & $\frac{1.74 \% \sim 12.04}{6.20}$ & $\frac{0.04 \sim 8.18}{2.92}$ & $\frac{181 \sim 7769}{2077}$ & $>0.99$ & $\frac{-56.8 \sim-47.7}{-51.2}$ & $\frac{-6.6 \sim 13.9}{3.6}$ & $\frac{\frac{-252.6}{\sim-241.6}}{-247.5}$ \\
\hline
\end{tabular}

Table 2. Water Quality Testing and Isotope Testing in Baode area

\begin{tabular}{|c|c|c|c|c|c|c|c|c|c|c|c|}
\hline \multirow[b]{2}{*}{ Project } & \multicolumn{7}{|c|}{ Ion content $/ \mathrm{mg} / \mathrm{L}$} & \multicolumn{2}{|c|}{ Isotope $/ \%$} & \multirow[b]{2}{*}{$\mathrm{pH}$} & \multirow{2}{*}{$\begin{array}{c}\text { Degree of } \\
\text { mineralization } \\
/ \mathrm{mg} / \mathrm{L}\end{array}$} \\
\hline & $\mathrm{Na}^{+}$ & $\mathrm{K}^{+}$ & $\mathrm{Mg}^{2+}$ & $\mathrm{Ca}^{2+}$ & $\mathrm{Cl}^{-}$ & $\mathrm{SO}_{4}^{2-}$ & $\mathrm{HCO}_{3}^{-}$ & $\begin{array}{c}\delta \mathrm{D}\left(\mathrm{H}_{2} \mathrm{O}\right. \\
)\end{array}$ & $\begin{array}{c}\delta^{18} \mathrm{O}(\mathrm{H} \\
\left.{ }_{2} \mathrm{O}\right)\end{array}$ & & \\
\hline $\begin{array}{c}\text { Coal seam } \\
\text { produced water }\end{array}$ & $\frac{225.0 \sim 5}{\frac{75.4}{374.3}}$ & $\frac{30.0 \sim 17}{\frac{4.7}{68.1}}$ & $\frac{0.2 \sim 5}{\frac{0.3}{30.9}}$ & $\frac{75.9 \sim 19}{\frac{3.4}{140.7}}$ & $\frac{202.2 \sim 6}{\frac{47.7}{357.3}}$ & $\frac{3.8 \sim 42}{\frac{.5}{13.7}}$ & $\frac{797.1 \sim 14}{\underline{32.0}} \frac{1019.3}{10.0}$ & $\frac{-92.9 \sim-8}{\frac{1.8}{-88.2}}$ & $\frac{-11.5 \sim-}{\frac{8.5}{-10.1}}$ & $\frac{7.0 \sim}{\frac{8.0}{7.3}}$ & $\frac{1494.7 \sim 2633.3}{2004.2}$ \\
\hline Surface water ${ }^{[17]}$ & $\frac{82 \sim 112}{97}$ & $\frac{3.3 \sim 22 .}{\frac{5}{12.9}}$ & $\frac{159 \sim 1}{\frac{91}{175}}$ & $\frac{320 \sim 54}{\frac{0}{430}}$ & $\frac{33 \sim 50}{41}$ & $\frac{95.3 \sim 3}{\frac{25}{180}}$ & $\frac{36 \sim 210}{123}$ & $\frac{-85.0 \sim-9}{\frac{0.0}{-87.5}}$ & $\frac{-8.0 \sim-8 .}{\frac{5}{-8.25}}$ & - & \\
\hline
\end{tabular}




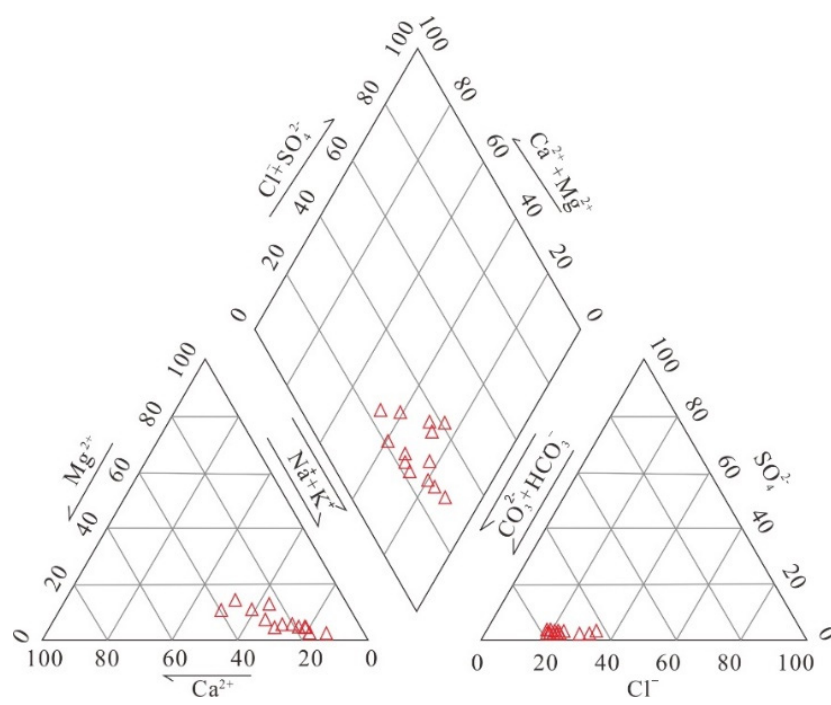

Fig.1. Piper diagram showing the distribution of anion and cation of the water produced from coalseam in Baode area

\subsubsection{Composition and isotope characteristics of coal seam produced water}

The chemical composition of coal seam produced water in Baode area (Table 2) showed that the $\mathrm{pH}$ value of coal seam produced water was between 7.0 and 8.0, with an average value of 7.3. It was weakly alkaline and belonged to the NaHCO3 water type (Fig.1). The coal seam produced by this area has large differences in water anion and cation composition. The cations are mainly $\mathrm{Na}+$ and $\mathrm{Ca} 2+$, the anions are mainly $\mathrm{HCO} 3-$ and $\mathrm{Cl}-$, the content of SO42- is less, and the degree of mineralization is lower. The salinity is similar, indicating that the water produced in the coal seam is close to the recharge area and the hydrodynamic conditions are more active.

The rain line equation of the Ordos Basin is $\delta \mathrm{D}(\mathrm{H} 2 \mathrm{O})$ $=6.88 \delta 18 \mathrm{O}(\mathrm{H} 2 \mathrm{O})+0.23(\mathrm{r}=0.9485)[16]$. The $\delta \mathrm{DH} 2 \mathrm{O}$ value of coal seam produced water in the study area is between $-92.9 \%$ - $81.8 \%$, with an average value of $-88.2 \%$; the $\delta 18 \mathrm{O}(\mathrm{H} 2 \mathrm{O})$ value is between $-11.5 \%$ and $-8.5 \%$, with an average value of $-10.1 \%$. The $\delta \mathrm{D}(\mathrm{H} 2 \mathrm{O})$ and $\delta 18 \mathrm{O}(\mathrm{H} 2 \mathrm{O})$ values of the coal seam water produced in this area have a good linear relationship (Fig.2). They are all distributed below the atmospheric precipitation line in the Ordos Basin, and generally have a characteristic of $\delta 18 \mathrm{O}(\mathrm{H} 2 \mathrm{O})$ weighting, similar to the $\delta \mathrm{D}(\mathrm{H} 2 \mathrm{O})$ and $\delta 18 \mathrm{O}(\mathrm{H} 2 \mathrm{O})$ values of surface water. It shows that the produced water from the coalbed methane wells in this area is supplied by external water.

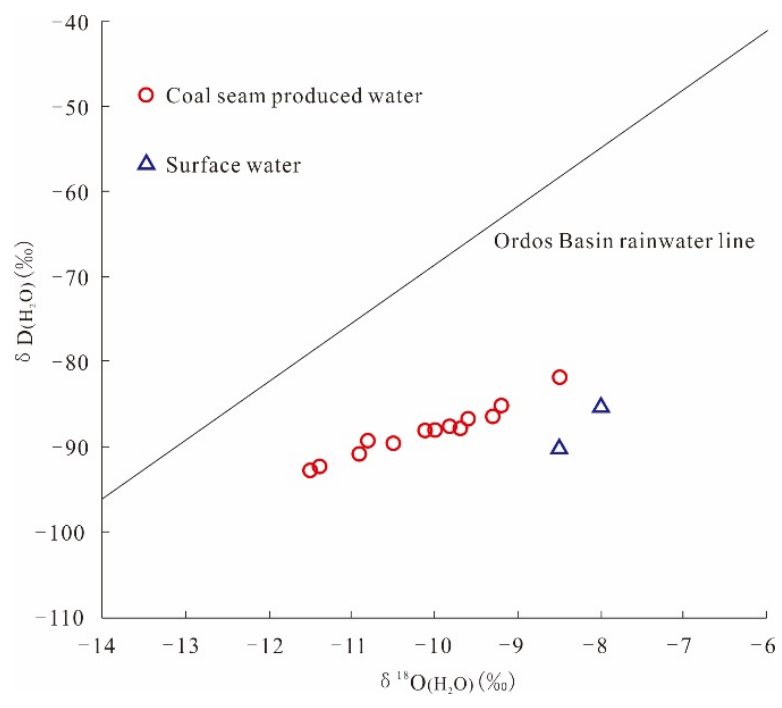

Fig.2. Distribution of hydrogen and oxygen isotopes of the water produced from coalseam in Baode area

\subsection{Discussion on the cause of coalbed methane}

\subsubsection{Analysis of $\delta^{13} \mathrm{C}\left(\mathrm{CH}_{4}\right)$-gas composition based on coalbed methane}

Scholars at home and abroad have proposed a number of methods and diagrams for identifying the genesis types of natural gas based on the characteristics of coal bed gas components and stable carbon isotopes [18-20]. The maximum vitrinite reflectance of the coal seam in Baode area is between $0.52 \%$ and $0.89 \%$. brought into the thermal simulation equation of coal established by Liu et al. [21], and the primary coalbed methane $\delta 13 \mathrm{C}(\mathrm{CH} 4)$ in this area is calculated to be between $-33.9 \%$ - $30.9 \%$. It is obviously heavier than the actual measured value of coalbed methane, which indicates that the coalbed methane in this area is not completely a primary pyrogenic coalbed methane and may have a secondary transformation effect. According to the Whiticar [22] plate analysis, the CBM sample points in the Baode area shifted upwards(Fig.3), and only a few points fell in the biogas interval area, indicating that the CBM in this area is not purely pyrogenic and biological. Genesis gas, but experienced secondary transformation in the later stage, forming "drying, lightening" coalbed methane. 


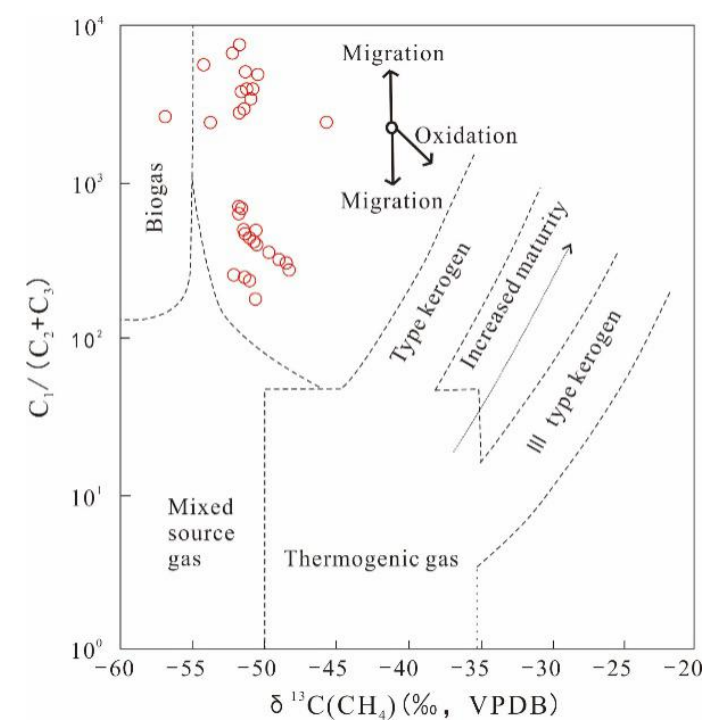

Fig.3. The identification of genetic types of coalbed methane $\delta^{13} \mathrm{C}\left(\mathrm{CH}_{4}\right)-\mathrm{C}_{1} /\left(\mathrm{C}_{2}+\mathrm{C}_{3}\right)$ in Baode area (Plate from Whiticar ${ }^{[22]}$ )

\subsubsection{Analysis of $\delta^{13} \mathrm{C}\left(\mathrm{CH}_{4}\right)-\delta D\left(\mathrm{CH}_{4}\right)$ based on coalbed methane}

Influenced by the $\delta \mathrm{D}(\mathrm{CH} 4)$ composition of sedimentary organic matter and the degree of thermal evolution, the $\delta \mathrm{D}(\mathrm{CH} 4)$ composition of marine source rocks is generally heavier than that of terrestrial freshwater lake source rocks. With the increase of the degree of coal evolution, alkanes have a concentration of heavy hydrogen [23-25]. The coal-bearing strata in Baode area are dominated by Shanxi Formation-Taiyuan Formation, and are dominated by river delta facies and lake-like terrestrial facies. They are not affected by seawater; The maximum vitrinite reflectance of the coal seam is between $0.52 \%$ and $0.89 \%$, which is in the low-maturity-maturity stage, and has a low degree of thermal evolution, so it is less affected by maturity, making the hydrogen isotope of $\mathrm{CH} 4$ gas lighter. Based on the analysis of Whiticar [22] identification plate (Fig.4), the CBM sample points in Baode area are mainly distributed in the range of thermogenic gas, and only a small part of them falls in the range of mixed genetic gas, indicating that the CBM in this area thermogenic gases are dominant and contain some biogenic gases.

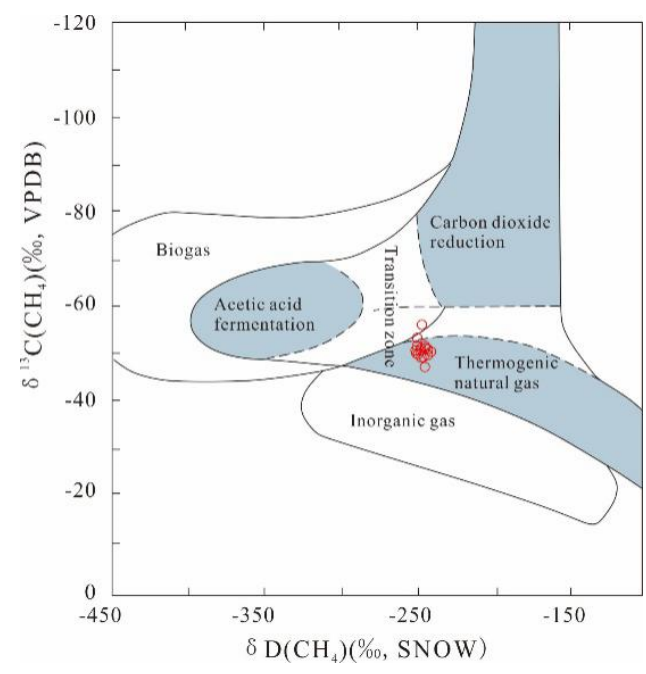

Fig.4. The identification of genetic types of coalbed methane $\delta^{13} \mathrm{C}\left(\mathrm{CH}_{4}\right)-\delta \mathrm{D}\left(\mathrm{CH}_{4}\right)$ in Baode area (Plate from Whiticar $\left.{ }^{[22]}\right)$

\subsubsection{Analysis of $\delta^{13} \mathrm{C}\left(\mathrm{CO}_{2}\right)-\delta^{13} \mathrm{C}\left(\mathrm{CH}_{4}\right)$ based on coalbed methane}

Under different environmental conditions, microorganisms generate biogas mainly through $\mathrm{CO} 2$ reduction and acetic acid fermentation [25-26]: $\mathrm{CO} 2$ reduction: $\mathrm{CO} 2+4 \mathrm{H} 2 \rightarrow \mathrm{CH} 4+2 \mathrm{H} 2 \mathrm{O}$; acetic acid fermentation: $\mathrm{CH} 3 \mathrm{COOH} \rightarrow \mathrm{CH} 4+\mathrm{CO} 2$. The $\delta 13 \mathrm{C}(\mathrm{CO} 2)$ value of the coalbed methane in Baode area is between $-6.6 \%$ $13.9 \%$, with an average value of $3.6 \%$, indicating that the lighter $813 \mathrm{C}(\mathrm{CO} 2)$ part of the coalbed methane in this area belongs to organic pyrogenic gas, and the $\delta 13 \mathrm{C}(\mathrm{CO} 2)$ heavier part may be related to microbial action. According to the $\delta 13 \mathrm{C}(\mathrm{CO} 2)-\delta 13 \mathrm{C}(\mathrm{CH} 4)$ coalbed methane classification map proposed by Smith and Pallasser (Fig.5), the biodegradation of $\mathrm{CH} 4$ and $\mathrm{CO} 2$ in the Baode area was affected by microbial degradation and metabolism, leading to the isotope generation and fractionation, showing $813 \mathrm{C}(\mathrm{CH} 4)$ Phenomenon of becoming lighter and $\delta 13 \mathrm{C}(\mathrm{CO} 2)$ becoming heavier. The coalbed methane sample points in the study area all fall within the area of biogenic gas and mixed genesis generated by $\mathrm{CO} 2$ reduction, reflecting that the coalbed methane in this area is mainly biogenic and mixed gases. 


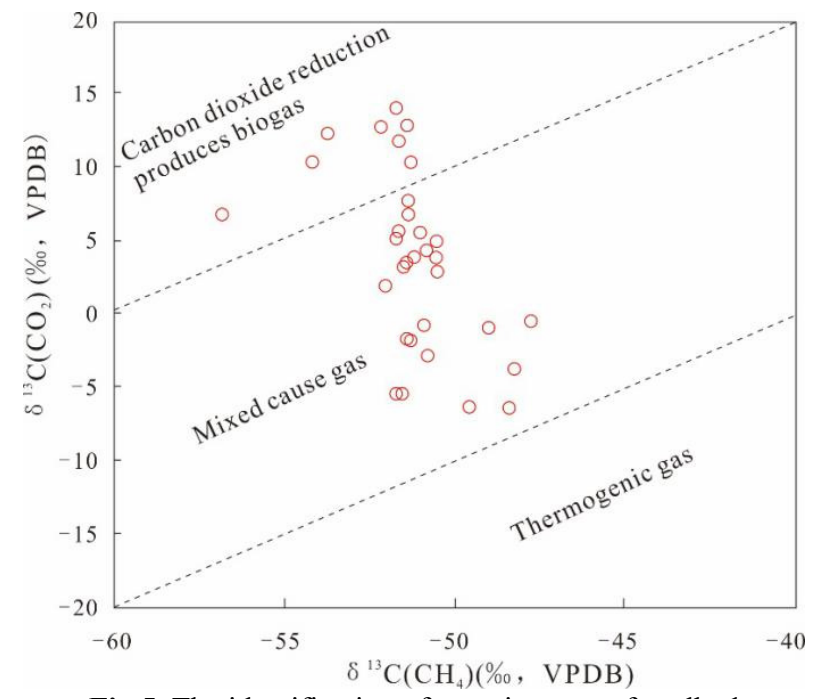

Fig.5. The identification of genetic types of coalbed methane $\delta^{13} \mathrm{C}\left(\mathrm{CO}_{2}\right)-\delta^{13} \mathrm{C}\left(\mathrm{CH}_{4}\right)$ in Baode area (Plate from Smith and Pallasser ${ }^{[26]}$ )

\subsubsection{Analysis of $\delta^{13} \mathrm{C}\left(\mathrm{CH}_{4}\right)$ - Water isotope produced in coal seam Based on Coalbed methane}

The above-mentioned research on the relationship between isotopes and components of coalbed methane shows that in addition to thermogenic gas, biogenic gas exists in Baode area, but the contribution ratio of $\mathrm{CO} 2$ reduction and acetic acid fermentation in biogenic gas cannot be determined specifically. Need further research. The $\delta \mathrm{D}(\mathrm{CH} 4)$ value of produced water in Baode area is between $-92.9 \% \sim-81.8 \%$. The $\delta \mathrm{D}(\mathrm{H} 2 \mathrm{O})$ value of coal seam produced water in this area was substituted into the formula of the $\mathrm{CO} 2$ reduction $(\delta \mathrm{D}(\mathrm{CH} 4)=\delta \mathrm{D}(\mathrm{H} 2 \mathrm{O})$ $-160 \%$ o $10 \%$ ) proposed by Whiticar et al [27]. The calculated $\delta \mathrm{D}(\mathrm{CH} 4)$ value was $-252.9 \% \pm 10 \%$ $-241.8 \% \pm 10 \%$, and substituted into the formula of acetic acid fermentation $(\delta \mathrm{D}(\mathrm{CH} 4)=0.143 \delta \mathrm{D}(\mathrm{H} 2 \mathrm{O})-384 \%) \quad, \quad$ The calculated $\delta$ DCH4 value is $-399.3 \% \sim-395.7 \%$. A comparative analysis of $\delta \mathrm{D}(\mathrm{CH} 4)$ shows that the measured value of $\delta \mathrm{D}(\mathrm{CH} 4)$ of coalbed methane in Baode area is between $-252.6 \%$ and $-241.6 \%$, which is closer to the calculated value of $\delta \mathrm{D}(\mathrm{H} 2 \mathrm{O})$ of the $\mathrm{CO} 2$ reduction pathway in formula of the $\mathrm{CO} 2$ reduction, indicating that the biogenic gas in the study area mainly passes carbon dioxide Reduction is formed.

According to the calculation formula proposed by Jenden et al. [28], it can be known that the proportion of $\mathrm{CO} 2$ in the biogenic gas generated in Baode area is $93 \%$ $\sim 100 \%$, indicating that most of the biogenic gas in this area passes the $\mathrm{CO} 2$ reduction pathway. Generated, which is consistent with the analysis results described above.

\subsubsection{Comprehensive analysis based on geological conditions}

The buried depth of the coal seam in Baode area is generally shallow, and the fractures are relatively developed, which can effectively improve the permeability of the coal seam. Groundwater can penetrate the coal seam through the fractures, which is beneficial to the generation of biogas. The scale of the fractures is not large, and there is no connection between the coal seam and the aquifer It can effectively prevent the CBM from escaping through the formation water, which is beneficial to the preservation of CBM. The study area undergoes late tectonic activities, strata are denuded or uplifted, atmospheric precipitation and surface water are recharged from the edge of the basin, and microorganisms are taken into the coal seam by the groundwater to absorb organic matter, which can generate a large amount of biogas through microbial degradation and metabolism.

The coal seam buried temperature in the study area is between $30 \sim 35{ }^{\circ} \mathrm{C}$, which is the best temperature for biogas generation. The coal rank is low, and the maximum vitrinite reflectance is between $0.52 \% \sim 0.89 \%$, Containing a small amount of gas-fertilized coal, suitable for biogas generation. The $\mathrm{pH}$ value of the water produced in the coal seam is between $7.0 \sim 8.0$, which is weakly alkaline, which is conducive to the survival of CH4 bacteria. The total sodium and potassium ions are between $250 \mathrm{mg} / \mathrm{L} \sim 600 \mathrm{mg} / \mathrm{L}$, which is good for the growth of anaerobic organisms. SO42- content is between $3.8 \mathrm{mg} / \mathrm{L} \sim 42.5 \mathrm{mg} / \mathrm{L}$. There are fewer sulfate-reducing bacteria that cannot inhibit the activity of CH4-producing bacteria, which is beneficial to the reproduction of $\mathrm{CH} 4$-producing bacteria. $\mathrm{HCO} 3$ - content is between $797.1 \mathrm{mg} / \mathrm{L} \sim 1432.0 \mathrm{mg} / \mathrm{L}$. There is a large amount of $\mathrm{HCO} 3-$, which provides sufficient $\mathrm{CO} 2$ for the later generation of biogas. The produced water from the coalbed gas wells in the study area $\mathrm{Ca} 2+, \mathrm{Mg} 2+, \mathrm{HCO} 3-$ are rich, SO42- is poor, and low in salinity. It is similar to the surface water ion composition and salinity, indicating that the hydrodynamic conditions of the coal seam in this area are more active, but in Below the salt reduction zone, it is beneficial for the large number of $\mathrm{CH} 4$-producing bacteria to multiply and generate biogas.

\section{Conclusions}

(1) In the coalbed methane composition of Baode area, the hydrocarbon gas is mainly $\mathrm{CH} 4$ and contains a small amount of ethane; the non-hydrocarbon gas mainly includes $\mathrm{CO} 2$ and $\mathrm{N} 2$; the drying coefficients are all greater than 0.99 , which belongs to very dry coalbed methane. The average value of $\delta 13 \mathrm{C}(\mathrm{CH} 4)$ is $-51.2 \%$, which is light; the average value of $\delta 13 \mathrm{C}(\mathrm{CO} 2)$ is $3.6 \%$, which is heavy; the average value of $\delta \mathrm{D}(\mathrm{CH} 4)$ is $-247.5 \%$, which has the characteristics of terrestrial biogas.

(2) The water produced from coal seams in Baode area is weakly alkaline and belongs to $\mathrm{NaHCO} 3$ type water. Among them, the cations are mainly $\mathrm{Na}+$ and $\mathrm{Ca} 2+$, the anions are mainly $\mathrm{HCO} 3-$ and $\mathrm{Cl}-$, the content of SO42- is poor, and the degree of mineralization is low, which is similar to the composition and mineralization of surface water ions. $\delta \mathrm{D}(\mathrm{H} 2 \mathrm{O})$ and $\delta 18 \mathrm{O}(\mathrm{H} 2 \mathrm{O})$ are distributed in Ordos Below the basin's atmospheric precipitation line, the values of $\delta \mathrm{D}(\mathrm{H} 2 \mathrm{O})$ and $\delta 18 \mathrm{O}(\mathrm{H} 2 \mathrm{O})$ 
are similar to the surface water. The hydrodynamic conditions of the coal seam in this area are relatively active, and there is replenishment of external water, which is conducive to the large number of $\mathrm{CH} 4$-producing bacteria to generate biogas.

(3) The coalbed methane in the Baode area is a mixture of thermogenic and biological genesis. It is dominated by thermal genesis and supplemented by biogenic gas generated through carbon dioxide reduction.

\section{references}

1. X.P. Liu, H.T. Zhao, X.X. Yan. NGGS.30(2019).

2. W.Q Hu, J.Z. Zhao, J. Li. NGGS.26(2015)

3. H.Y. Chao, Y.B. Wang. J CHINA COAL $\operatorname{SOC.41}(2016)$

4. Z.J. Xu, Q.F. Liu, Q.M. Zheng. J CHINA COAL SOC.41(2016)

5. P. Xia, F.G. Zeng, X.X. Song. J CHINA COAL SOC.44(2019)

6. X.Z. Ma, Y. Song, S.B. Liu. NAT GAS IND.31(2011)

7. G.H. Li, H. Zhang. SCI CHINA: EARTH SCI.43(2013)

8. S.Z. Meng, W.Z. Zhang, R.H. Mo. COAL SCI TECHNO.43(2015)

9. W.G. Tian, D.Z. Tang, Z.L. Wang. Geological Journal of China Universities.18(2012)

10. Y. Li, S.Z. M, P. Wu. Nature gas industry.37(2017)

11. F. Yang, X.C. Yang, B. Jiang. COAL SCI TECHNO.42(2014)

12. H.D. Chen, B. Jiang, Z.H. Qu. J CHINA COAL SOC.39(2014)

13. Y.L. Shen, Y. Qin, J. Shen. NAT GAS IND. 37(2017)

14. Y. Wang, S.Y. Chen, H.Y. Liang. ACTA SEDIMENT SIN.34(2016).

15. Z.S. Hou, S.Y.Chen, Y. Wang. J. Palaeogeogr.20(2018)

16. G.C. Hou, M.S. Zhang. B GEOL P H.( 2008).

17. W.G. Tian, L.Y. Shao, B. Sun. NAT GAS IND.34(2014)

18. Y.W. Ju, Q.G. Li, Z.F. Yan. J CHINA COAL SOC. 39(2014)

19. J.J. Tao, J. Shen, J.Y. Wang. GEOL J CHINA UNIV. 25(2019).

20. W,Q. Hu, Y.B. Li, X. Chen. NGGS.31(2020)

21. W.H. Liu, Q.Y. Liu, Y.C. Xu. NGGS.14(2003)

22. M J. Whiticar. Chem. Geol. 161(1999).

23. X.F. Wang, W.H. Liu, Y.H. Xu. SCI CHINA SER D. 42(2012)

24. X.F. Wang, W.H. Liu, Y.C Xu. NGGS.17(2006)

25. M. Schoell. GEOCHIM COSMOCHIM AC. 44(1980)

26. J.W. Smith, R.J. Pallasser. AAPG. 80(1996)
27. M.J. Whiticar, E. Faber, M. Schoell. GEOCHIM COSMOCHIM AC.50(1986)

28. P.D. Jenden, I.R. Kaplan. Appl. Geochemistry. 1(1986) 